\title{
PERANAN PENYULUH PADA USAHATANI PADI DI MASA PANDEMI COVID-19 DI DESA SAMBORA KECAMATAN TOHO KABUPATEN MEMPAWAH
}

\author{
(The Role Of Agricultural Extension Worker In Rice Farming In Covid-19 Pandemic \\ In Sambora Village, Mempawah Regency)
}

Ellyta, Wahyu Sasmito dan Ekawati

Program Studi Agribisnis, Universitas Panca Bhakti

Jalan Komodor Yos Sudarso Pontianak

Penulis koresponden : el_lyta@yahoo.com

Article Submitted: 10-06-2021

Article Accepted: 03-08-2021

\begin{abstract}
The purpose of this study was to determine the role of field extension workers on the productivity of rice farming. During the Covid-19 pandemic, physical contact and social contact were greatly reduced, it had an impact on the role that extension workers. To measure the data on the role of the extension worker, a Likert scale is used.. The results showed that a slowdown in extension activities, indicated by an average of over $70 \%$ of farmers saying there was no extension to farmers individually or in groups. The level of the role of the extension worker is 1.84 which is included in the Medium category. This means that from the overall average value of the role of the extension agent starting from the extension agent as an advisor, as an organizer, as a technician, as a liaison and as an agent of renewal, the role is sufficient for farmers.
\end{abstract}

Keywords: pandemic, covid-19, role, agricultural extension worker, rice.

\section{PENDAHULUAN}

Penyuluhan Pertanian memiliki peran yang sangat strategis di dalam mendukung dan mengawal program utama pembangunan pertanian, untuk tercapainya Empat Sukses Pembangunan Pertanian, yaitu: (1) Swasembada dan Swasembada Berkelanjutan; (2) Diversifikasi Pangan; (3) Peningkatan Nilai Tambah, dan Daya Saing Ekspor, dan (4) Peningkatan Kesejahteraan Petani (Faqih, 2014). Peran penyuluh dalam pendampingan petani sangat diperlukan dalam rangka peningkatan produksi pertanian khususnya padi yang akhirnya dapat meningkatkan kesejahteraan petani yang dapat dilihat dari meningkatnya taraf hidup dan pendapatan petani (Inten, et al, 2017)

Padi merupakan tanaman yang sangat dibutuhkan oleh rakyat Indonesia karena tanaman padi menghasilkan makanan pokok masyarakat Indonesia dalam bentuk beras. Sebagai tanaman pangan utama, padi menjadi komoditi utama yang terus digalakkan untuk ditanam dalam upaya mencapai swasembada pangan, ketahanan pangan, dan kedaulatan pangan.

Pendapatan petani padi Desa Sambora mengalami fluktuasi akibat turun naiknya produksi. Sebagai salah satu Desa yang ada di Kecamatan Toho yang memiliki luas lahan sektor tanaman pangan terbesar yakni padi dan menjadi penyumbang hasil pertanian dari Kabupaten Mempawah, fluktuasi produktivitas padi di Desa Sambora dapat mempengaruhi kestabilan produksi padi desa tersebut bahkan di Kabupaten Mempawah. Tahun 2017 produktivitasnya 3,2 ton/ha, tahun 2018 produktivitas padi sawah meningkat menjadi 
4,2 ton/ha, dan pada tahun 2019 produktivitas padi sawah turun menjadi 4 ton/ha (WKPP Kecamatan Toho, 2020). Penurunan produksi ini tentu saja menjadi hal yang menarik untuk diketahui lebih lanjut penyebabnya, dan perlu dilihat dari sudut pandang penyuluhan dimana penyuluhan secara intensif dilakukan di WKPP Kecamatan Toho dimana Desa Sambora merupakan bagian dari wilayah kerja.

Pandemi Covid-19 mendera dunia tidak terkecuali Indonesia khususnya di Desa Sambora. Sebagai upaya untuk menguragsi penyebaran penyakit yang diakibatkan virus corona, seluruh kegiatan yang mengakibatkan kerumunan dihindari, kontak fisik dan kontak sosial juga dikurangi. Sedangkan kegiatan penyuluhan dan kegiatan pertanian harus tetap berjalan untuk menjaga produksi pangan daerah dan nasional. Dalam kegiatan penyuluhan, tentu saja peranan-peranan yang dilaksanakan penyuluh menjadi urat nadi keberhasilan penyuluhan Desa Sambora. Peranan penyuluhan merupakan faktor yang penting dalam keputusan adopsi suatu inovasi dan pengembangan produksi. Informasi yang telah diberikan dalam proses penyuluhan berisikan materi dan cara yang dapat memperbaiki kualitas usahatani antara lain sistem penanaman Jajar Legowo dan pengendalian hama dan penyakit tanaman, disamping materi-materi lainnya merupakan bentuk-bentuk inovasi dengan harapan petani akan mengadopsinya. Sejalan dengan pernyataan Ilham (2010) penyuluh pada dasarnya dapat berperan sebagai pengisi kehampaan pedesaan, penyebar hasil-hasil penelitian, pelatih pengambilan keputusan, rekan pemberi semangat, pendorong peningkatan produksi suatu komoditas, dan pelayan pemerintah. Kenyataan yang terjadi saat pelaksanaan di lapangan, adopsi inoasi dalam bentuk penyuluhan belum berjalan dengan optimal. Hal ini salah satunya ditandai dengan masih rendahnya produktivitas. Adapun tujuan penelitian ini adalah untuk mengetahui peranan penyuluhan dalam upaya peningkatan produktivitas padi di Desa Sambora.

\section{METODE PENELITIAN}

Metode penelitian ini adalah penelitian kuantitatif. Penelitian kuantitatif adalah penelitian yang datanya merupakan angka atau data non angka yang diangkakan (data kualitatif dikuantitatifkan), lalu diolah dengan menggunakan rumus statistik tertentu, dan diinterpretasikan dalam rangka menguji hipotesis yang telah disiapkan lebih dahulu, serta lazim bertujuan mencari sebab akibat (kausalitas) sesuatu. Sukidin dan Mundir (2005). Variabel yang diteliti dalam penelitian ini adalah variable peraran penyuluh dimana pertanyaan-pertanyaan dalam kuesioner berbentuk kualitatif sedangkan dari jawabannya setelah diolah akan berbentuk angka-angka. Adapun angka-angka tersebut berasal dari jawaban pertanyaan yang disusun berdasarkan skala likert. Sejalan dengan variabel penelitian yang digunakan Novianti (2019), variabel yang diteliti merupakan variabel kualitatif sementara jenis data yang yang diperlukan adalah data kuantitatif sehingga penelitian ini menggunakan data berupa data kualitatif yang dikuantitatifkan untuk mempermudah pemprosesaan pengolahan data dengan menggunakan skala likert dan data diwujudkan dalam bentuk angka. Metode yang dipakai dalam pengumpulan data adalah dengan metode survei. Menurut Kurniawan \& Puspitaningtyas (2016), metode survey diarahkan untuk mengetahui dan mempelajari data dari sampel yang diambil dari populasi, sehingga ditemukan kejadian kejadian relatif, distribusi, serta hubungan-hubungan antara variabel. Penelitian survey dapat dilakukan pada populasi besar maupun kecil. Penelitian dilaksanakan di Desa Sambora Kecamatan Toho Kabupaten Mempawah, Kalimantan Barat., Metode penentuan sampel petani dalam penelitian ini dilakukan dengan cara sengaja (purposive sampling), Adapun 
jumlah anggota kelompok tani di WKPP Kecamatan Toho Desa Sambora tergabung dalam Gapoktan Usaha Baru yang terbagi dalam 9 Kelompok Tani yang berjumlah 350 orang petani. Menurut Suparmoko (2005), bahwa untuk menentukan besarnya persentase dengan memperhatikan hal-hal sebagai berikut: besarnya populasi, apabila populasi besar maka persentase yang kecil saja sudah dapat memenuhi syarat, besarnya sample hendaknya tidak kurang dari 30, dan sample seyogyanya sebesar mungkin selama dana dan waktu masih dapat terjangkau

Menurut Suparmoko (2005), apabila sama sekali tidak ada pengetahuan tentang besarnya varians dari populasi, maka cara terbaik menetapkan sample penelitian adalah cukup dengan mengambil persentase (\%) tertentu, yaitu 5\%, 10\%, $15 \%$ dari keseluruhan jumlah populasi.

Berdasarkan pendapat tersebut diatas maka maka jumlah aspek yang akan diambil (n) adalah $10 \%$ dari jumlah seluruh petani (N) sebesar 350 orang petani, sehingga :

$$
\begin{aligned}
& \mathrm{n}=\mathrm{N} \times 10 \% \\
& \mathrm{n}=350 \times 10 \%=35
\end{aligned}
$$

Jadi, jumlah sempel yang diambil sebanyak 35 orang petani.

Data yang dikumpulkan meliputi data primer dan data sekunder. Sumber data primer berasal dari hasil wawancara dengan responden menggunakan instrument kuesioner, sedangkan data sekunder diperoleh dari Kantor BPP Kecamtan Toho, BPS Kabupaten Mempawah, dan Dinas Pertanian Kabupaten Mempawah. Berpedoman teori menurut Suhardiyono (1992), dan penelitian Sundari et al (2015) serta Faqih (2014) seorang penyuluh memiliki peranan antara lain sebagai penasehat, organisator, teknisi, penghubung dan agen pembaharuan di bidang pertanian. Variable penelitian peranan penyuluh merujuk pada pendapat tersebut.

Data yang diperoleh dari hasil penelitian terhadap aspek karakteristik petani, peranan penyuluh sebagai penasihat, sebagai organistoris, sebagai penghubung, dan sebagai agen pembaharuan, selanjutnya ditabulasikan, diolah secara kuantitatif dan hasilnya dideskriptifkan, maksudnya adalah data sosial berbentuk deskripsi kalimat yang diberi bobot/nilai agar bisa dihitung/dianalisis. Untuk mengukur data peranan penyuluh digunakan skala likert.

Skala likert digunakan untuk mengukur sikap, pendapat, dan persepsi seseorang atau sekelompok orang tentang fenomena sosial. Instrumen penelitian yang menggunakan skala likert dibuat dalam bentuk cheklis, pilihan ganda atau bahkan dengan pertanyaan atau pernyataan terbuka (Sugiyono, 2016).

Jawaban hasil pengukuran respon pada setiap item variabel dianalisis dengan berpedoman pada pendapat Sugiyono (2016), dengan kriteria penilaian skor terhadap jawaban sebagai berikut :
a. Berperan
: 3
b. Sedang/ragu-ragu
$: 2$
c. Rendah
$: 1$

Keputusan analisis berpedoman pada Sugiyono (2016), bahwa kriteria responden dilihat dari nilai persentase capaian nilai masing-masing kriteria. Selanjutnya dari hasil pengolahan data untuk melihat kriteria peran penyuluh yang dinilai oleh petani responden ditentukan dengan mengacu pada perhitungan rentang skor dari Sudjana (2005), dimana rentang skor dihitung dengan rumus sebagai berikut :

Total Range $=$ Skor Tertinggi -

Skor Terendah /

Rentang Skor

Tertinggi

Rata - rata Range $=\underline{\text { Total Range }}$ Total Sampel

Dimana :

Skor Tertinggi $=35 \times 3=105$

Skor Terendah $=35 \times 1=35$

Total Range $=105-35 / 3$

$=23,33$

Rata-rata Range $=23,33 / 35=0,7$

Dengan menggunakan pedoman tersebut, penelitian menentukan tiga jenjang kriteria jawaban, yaitu : 
1. Berperan

2. Sedang/ragu-ragu

3. Rendah

Kaidah keputusan dari tingkat jawaban responden ditafsirkan sebagai berikut :
a. > 2,40-3,00 : Peran Tinggi
b. $>1,70-2,40$ : Peran Sedang
c. $1,00-1,70$ : Peran Rendah

\section{HASIL DAN PEMBAHASAN}

Dari penelitian ini diperoleh informasi bahwa karakteristik responden menurut umur berkisar antara 30-60 tahun, tingkat Pendidikan terbesar adalah SD, luas lahan padi yang dikelola berkisar antara 0,52 hektar, rata-rata jumlah produksi padi adalah 3,2 ton, dan rata-rata produktivitas padi adalah 2,79 ton per hektar. Hasil pengukuran peranan penyuluh secara umum masuk pada kategori sedang..

\section{Analisis Tingkat Peranan Penyuluh Terhadap Petani.}

Di Desa Sambora terdapat seorang penyuluh pertanian dengan kompetensi tingkat pendidikan sarjana dengan luas wilayah kerja 1197 hektar dan membina sembilan kelompok tani. Wijaya et al (2019) menyatakan penyuluh memiliki peranan penting sebagai ujung tombak serta jembatan antara pemerintah dan petani sebagai pelaku utama sehingga dituntut memiliki pengetahuan, informasi yang memadai untuk petani dan kemampuan untuk akses dan tanggap terhadap perkembangan teknologi.

Kedudukan penyuluh sangat strategis dalam pembangunan, khususnya dalam melakukan perubahan perilaku kepada pelaku utama dan pelaku usaha. Peran tersebut menunjukkan bahwa pekerjaan penyuluhan adalah pekerjaan profesi yang hanya dapat dilakukan oleh seorang penyuluh yang memiliki keahlian khusus (Zulfikar, Amanah, Asngari, 2018).

\section{Penyuluh Sebagai Penasehat.}

Hasil analisis rata- rata tanggapan responden pada variabel pengamatan penyuluh sebagai penasehat dapat dilihat pada tabel 1 berikut.

Tabel 1. Rata-rata Tanggapan Responden Terhadap Penyuluh Sebagai Penasehat

\begin{tabular}{|c|c|c|}
\hline \multicolumn{3}{|c|}{ Rata - rata Tanggapan Responden } \\
\hline Item Pernyataan & Skor & Kategori \\
\hline \multicolumn{3}{|c|}{$\mathrm{A}$} \\
\hline $\begin{array}{l}\text { Penyuluh memberikan saran agar petani padi } \\
\text { menggunakan sistem Jajar Legowo }\end{array}$ & 1,77 & Sedang \\
\hline $\begin{array}{l}\text { Penyuluh memberikan saran agar petani padi } \\
\text { melaksanakan PHT pada tanaman }\end{array}$ & 1,66 & Rendah \\
\hline $\begin{array}{l}\text { Penyuluh memberikan saran agar petani padi } \\
\text { melaksanakan pemberian pupuk sesuai dosis } \\
\text { anjuran }\end{array}$ & 1,97 & Sedang \\
\hline $\begin{array}{l}\text { Penyuluh memberikan saran agar petani padi } \\
\text { memberikan pupuk pada waktu yang dianjurkan }\end{array}$ & 1,94 & Rendah \\
\hline Rata- rata Skor & 1,84 & Sedang \\
\hline \multicolumn{3}{|c|}{$\bar{B}$} \\
\hline $\begin{array}{l}\text { Penyuluh memberikan saran agar petani } \\
\text { membentuk koperasi unit desa }\end{array}$ & 1,4 & Rendah \\
\hline Jumlah & $\mathrm{A}+\mathrm{B}$ & 3,24 \\
\hline Rata - rata skor & 1,62 & Rendah \\
\hline
\end{tabular}

Sumber : Hasil Analisis Data, 2020 
Berdasarkan Tabel 1 di atas terlihat dari hasil rata-rata nilai skor secara keseluruhan bahwa penyuluh sebagai penasehat berada pada kategori rendah, dimana rata-rata nilai skor sebesar 1,62. Sementara rata-rata tanggapan paling kecil berada pada item pernyataan bahwa Penyuluh memberikan saran agar petani membentuk koperasi unit desa dengan rata-rata nilai skor 1,40 dimana termasuk dalam kategori rendah.

Hingga sekarang belum terbentuk koperasi unit desa padahal pembentukan koperasi unit desa merupakan hal sangat penting bagi petani sebagai alternatif dalam memperoleh modal untuk menjalankan proses produksi, memperoleh sarana produksi, dan juga membantu memasarkan beras yang dihasilkan petani.. Sejalan dengan pendapat Hasan (2014) yaitu koperasi pertanian memegang peranan penting dalam mensejahterakan petani. Peranan tersebut meliputi pasokan input yang diperlukan oleh petani, prosesing dan pemasaran hasil. Didukung oleh penelitian Handayani dan Rahmadania (2020) yang menyatakan koperasi khususnya KUD dapat mengembangkan kegiatan usaha dan meningkatkan penghasilan anggota, membantu pemasaran, dan membantu membuka lapangan pekerjaan baru. Selain itu Antriyandarti (2018) menyatakan koperasi di Kabupaten Purworejo telah berhasil menerapkan sistem yang siap bersaing di era industri 4.0 dalam rantai nilai pemasaran produk kelapa. Koperasi pertanian di Kabupaten Purworejo menjalankan fungsi sebagai pengumpul, produksi, dan manufacturing, pemasaran serta pendampingan kepada petani yang semuanya dilakukan dengan teknologi mutakhir dan berbasis internet secara terpadu dan terintegrasi.

Terdapat skor rendah pada pernyataan penyuluh memberikan saran agar petani padi menggunakan sistem tanam jajar legowo, melaksanakan PHT dan penyuluh memberikan saran agar petani membentuk koperasi unit desa. Saran secara langsung dalam bentuk kunjungan kurang diberikan oleh penyuluh karena adanya pembatasan pergerakan sosial. Hal ini bukan berarti penyuluh sama sekali tidak memberikan saran, namun nasehat dalam budidaya padi dilakukan dengan media yaitu melalui telpon dan aplikasi what's up.

\section{Penyuluh Sebagai Organisatoris.}

Hasil analisis rata- rata tanggapan responden pada variabel pengamatan penyuluh sebagai Organisatoris dapat dilihat pada tabel 2 berikut.

Tabel 2. Rata-rata tanggapan Responden Terhadap Penyuluh Sebagai Organistoris

\begin{tabular}{lll}
\hline \multicolumn{1}{c}{ Rata - rata Tanggapan Responden } & \\
\hline \multicolumn{1}{c}{ Item Pernyataan } & Skor & Kategori \\
\hline $\begin{array}{l}\text { Penyuluh mendampingi petani dalam pembentukan kelompok tani. } \\
\text { Penyuluh mendampingi petani dalam menyusun RDKK. }\end{array}$ & 2,69 & Tinggi \\
\hline Penyuluh membantu memfasilitasipetani dalammengadakan diskusi. & 2,37 & Sedang \\
\hline $\begin{array}{l}\text { Penyuluhmengajakpetani belajar mengajarbersama dalamkelompok } \\
\text { tani. }\end{array}$ & 1,94 & Sedang \\
\hline $\begin{array}{l}\text { Penyuluh mengajak petani memanfaatkan kelompok tani sebagai } \\
\text { wadah kerjasama antar petani. }\end{array}$ & 2 & Sedang \\
\hline $\begin{array}{l}\text { Penyuluh mengajakpetani mengembangkan kelompok tani sebagai } \\
\text { unit/wadah produksi bers ama. }\end{array}$ & 2,06 & Sedang \\
\hline \multicolumn{1}{c}{ Rata - rata skor } & 2,22 & Sedang \\
\hline
\end{tabular}




\section{B}

\begin{tabular}{ccc}
$\begin{array}{l}\text { Penyuluh aktif memantau petani dalam pengembangan usahatani } \\
\text { terutama dalam perluasan }\end{array}$ & 1,74 & Sedang \\
\hline $\begin{array}{c}\text { Penyuluh aktif memantau kegiatan petani dalam menggunakan } \\
\text { kelompok sebagai sarana bekerja sama antar anggota }\end{array}$ & 1,83 & Sedang \\
\hline Rata - rata skor & 1,79 & Sedang \\
\hline Jumlah Skor & A+B & \\
\hline Rata - rata skor & 2 & Sedang \\
\hline
\end{tabular}

Sumber : Hasil Analisis Data, 2020.

Berdasarkan Tabel 2 di atas terlihat hasil rata-rata nilai skor penyuluh adalah 2 yang berarti peran sebagai organistoris berada pada kategori sedang. Penyuluh sangat memanfaatkan keberadaan kelompok tani dalam menyampaikan informasi dan tetap memberikan penguatan kepada kelompok tani. Hal ini didukung oleh penelitian Wardani dan Anwarudin (2018) peran penyuluh pertanian berpengaruh signifikan terhadap penguatan kelompok tani. Peran penyuluh dan penguatan kelompok tani berpengaruh nyata terhadap kemandirian kelompok tani. Pembentukan kelompok tani didasarkan kepada kesamaan tujuan dan pekerjaan dari anggotanya. Dasar inilah yang terus dibangkitkan oleh penyuluh agar petani menyadarinya dan bahkan mengetahui kemanfaatan ikut serta dalam kelompok tani. Syamsu (2011) mengatakan kelompok tani yang terbentuk atas dasar adanya kesamaan kepentingan diantara petani menjadikan kelompok tani tersebut dapat eksis dan mampu untuk melakukan akses kepada seluruh sumber daya seperti sumber daya alam, manusia, modal, informasi, serta sarana dan prasarana dalam mengembangakan usaha tani yang dilakukan. Dari uraian tersebut maka peranan penyuluh sebagai organisatoris penting untuk diperhatikan dan perlu ditingkatkan guna mencapai tujuan kelompok tani.

\section{Penyuluh Sebagai Teknisi.}

Hasil analisis rata- rata tanggapan responden pada variabel pengamatan penyuluh sebagai teknisi dapat dilihat pada tabel 3 berikut.

Tabel 3. Rata-rata tanggapan Responden Terhadap Penyuluh Sebagai Teknisi

\begin{tabular}{lll}
\hline \multicolumn{1}{c}{ Rata - rata Tanggapan Responden } \\
\hline \multicolumn{1}{c}{ Item Pernyataan } & Skor & Kategori \\
\hline $\begin{array}{l}\text { Penyuluhberperan dalam mengadakan praktek atau pelatihan } \\
\text { cara menghitung dosis pemberian pupuk berimbang sesuai } \\
\text { anjuran }\end{array}$ & 1,86 & Sedang \\
\hline $\begin{array}{l}\text { Penyuluhberperan dalam mengadakan praktek atau pelatihan } \\
\text { cara menghitung waktu pemberian pupuk berimbang sesuai } \\
\text { anjuran }\end{array}$ & 1,91 & Sedang \\
\hline $\begin{array}{l}\text { Penyuluhberperan dalam mengadakan praktek atau pelatihan } \\
\text { penerapan pengendalian H/Pdengan sistemPHT sesuaianjuran }\end{array}$ & 1,60 & Rendah \\
\hline $\begin{array}{l}\text { Penyuluhberperan dalam mengadakan praktek atau pelatihan } \\
\text { penerapan pengaturan jarak tanam padi menggunakan sistem } \\
\text { jejar legowo }\end{array}$ & 1,91 & Sedang \\
\hline \multicolumn{1}{c}{ Rata - rata skor } & 1,82 & Sedang \\
\hline
\end{tabular}

Sumber : Hasil Analisis Data, 2020

Jika dilihat dari hasil rata-rata nilai skor secara keseluruhan bahwa penyuluh sebagai teknisi berada pada kategori sedang dimana rata-rata nilai skor sebesar 1,82 . Penyuluh 
sebagai teknisi yaitu seorang penyuluh dituntut untuk memiliki pengetahuan dan keterampilan teknis mengenai materi yang disuluhkan yaitu berupa pemupukan, PHT dan sistem tanam. Kemampuan teknis ini dicontohkan kepada petani baik secara langsung maupun tidak langsung. Prasarana demplot sudah tersedia di Desa Sambora, namun belum optimal dimanfaatkan untuk memberikan contoh secara langsung kepada petani. Untuk itu berdasarkan uraian tersebut di atas maka perlu adanya peningkatan peranan penyuluh sebagai teknisi. Mardliyah dan Arsana (2018) mengatakan produktivitas padi organik dapat meningkat dilihat dari keberhasilan petani dalam mengadopsi penerapan teknologi yang diberikan oleh penyuluh. Teknologi yang diadopsi terdiri dari pengolahan tanah, benih, penanaman, pengairan, pemupukan, pengendalian hama dan penyakit, panen dan pasca panen. Dari pernyataan tersebut dapat disimpulkan kemampuan penyuluh sebagai teknisi dituntut untuk dapat menjadi sumber teknologi dan dapat memberikan informasi yang sifatnya teknis atau aplikatif dalam hubungannya dengan budidaya tanaman padi.

\section{Penyuluh Sebagai Penghubung.}

Hasil analisis rata- rata tanggapan responden pada variabel pengamatan penyuluh sebagai Penghubung dapat dilihat pada tabel 4 berikut.

Tabel 4. Rata-rata tanggapan Responden Terhadap Penyuluh Sebagai Penghubung

\begin{tabular}{|c|c|c|}
\hline \multicolumn{3}{|c|}{ Rata - rata Tanggapan Responden } \\
\hline Item Pernyataan & Skor & Kategori \\
\hline \multicolumn{3}{|l|}{$\mathrm{A}$} \\
\hline Penyampai Aspirasi petani dalam programa penyuluhan. & 2,29 & Sedang \\
\hline $\begin{array}{l}\text { Penyampai peraturan-peraturan dari pemerintah dalam bidang } \\
\text { pertanian. }\end{array}$ & 2,37 & Sedang \\
\hline $\begin{array}{l}\text { Penyampai kebijakan-kebijakan dari pemerintah dalam bidang } \\
\text { pertanian }\end{array}$ & 2,31 & Sedang \\
\hline Penghubung petani dengan peneliti. & 1,66 & Rendah \\
\hline Penghubung petani dengan Dinas Pertanian & 2,26 & Sedang \\
\hline Rata - rata skor & 2,18 & Sedang \\
\hline \multicolumn{3}{|l|}{$\mathrm{B}$} \\
\hline $\begin{array}{l}\text { Penyuluh aktif dalam memberikan informasi inovasi terbaru } \\
\text { tentang teknologi maupun teknik budidaya yang akan digunakan } \\
\text { untuk usahatani }\end{array}$ & 1,8 & Sedang \\
\hline \multicolumn{3}{|l|}{$\mathrm{C}$} \\
\hline $\begin{array}{l}\text { Penyuluh mengajarkan petani dalam penerapan teknologi terbaru } \\
\text { seperti penggunaan mesin panen }\end{array}$ & 1,71 & Sedang \\
\hline $\begin{array}{l}\text { Penyuluh memfasilitasi petani guna memperoleh pembelajaran } \\
\text { tentang teknologi terbaru untuk mengembangkan usahatani }\end{array}$ & 1,83 & Sedang \\
\hline Rata - rata skor & 1,77 & Sedang \\
\hline Jumlah skor & $\mathrm{A}+\mathrm{B}+\mathrm{C}$ & \\
\hline Rata - rata skor & 1,92 & Sedang \\
\hline
\end{tabular}

Sumber : Hasil Analisis Data, 2020

Berdasarkan Tabel 4 terlihat bahwa rata-rata nilai skor adalah 1,92 berarti peran penyuluh sebagai penghubung berada pada kategori sedang. Rata-rata petani dan keluarga tani sudah memiliki alat komunikasi sehingga sangat dimungkinkan komunikasi dilakukan dengan menggunakan media.

Jika dilihat dari klasifikasi tingkat pendidikan petani responden mayoritas 
tergolong rendah, namun bisa membaca dan menulis. Kemampuan ini bisa dimanfaatkan petani dan penyuluh untuk berkomunikasi dan memfasilitasi informasi. Informasi dan materi dari pemerintah yang mendesak untuk disampaikan maka diinformasikan dengan alat komunikasi telepon seluler kepada petani atau keluarga petani. Menurut Suhardiyono (1992) penyuluh bertugas menyampaikan hasil temuan lembaga penelitian kepada petani. Sebaliknya, petani berkewajiban melaporkan pelaksanaan penerapan hasil temuan lembaga penelitian yang dianjurkan tersebut kepada penyuluh pertanian sebagai penghubung, selanjutnya penyuluh menyampaikan hasil penerapan teknologi yang dilakukan oleh petani kepada lembaga penelitian yang terkait sebagai bahan referensi lebih lanjut. Menurut Rahmawati et al. (2019), kinerja penyuluh pertanian dianggap baik, jika dapat memfasilitasi petani dalam proses usahatani, pengelolaan pasca panen sampai penyerapan produk akhir oleh pasar. Pada peran ini masuk pada kategori sedang yang berarti penyuluh tetap melakukan tugasnya sebagai penghubung dalam menyampaikan aspirasi petani ke Dinas dan penyuluh juga tetap menyampaikan informasi dan kebijakan pemerintah kepada petani.

\section{Penyuluh Sebagai Agen Pembaharuan}

Hasil analisis rata- rata tanggapan responden pada variabel pengamatan penyuluh sebagai Agen Pembaharuan dapat dilihat pada tabel 5 berikut.

Tabel 5. Rata-rata tanggapan Responden Terhadap Penyuluh Sebagai Agen Pembaharuan

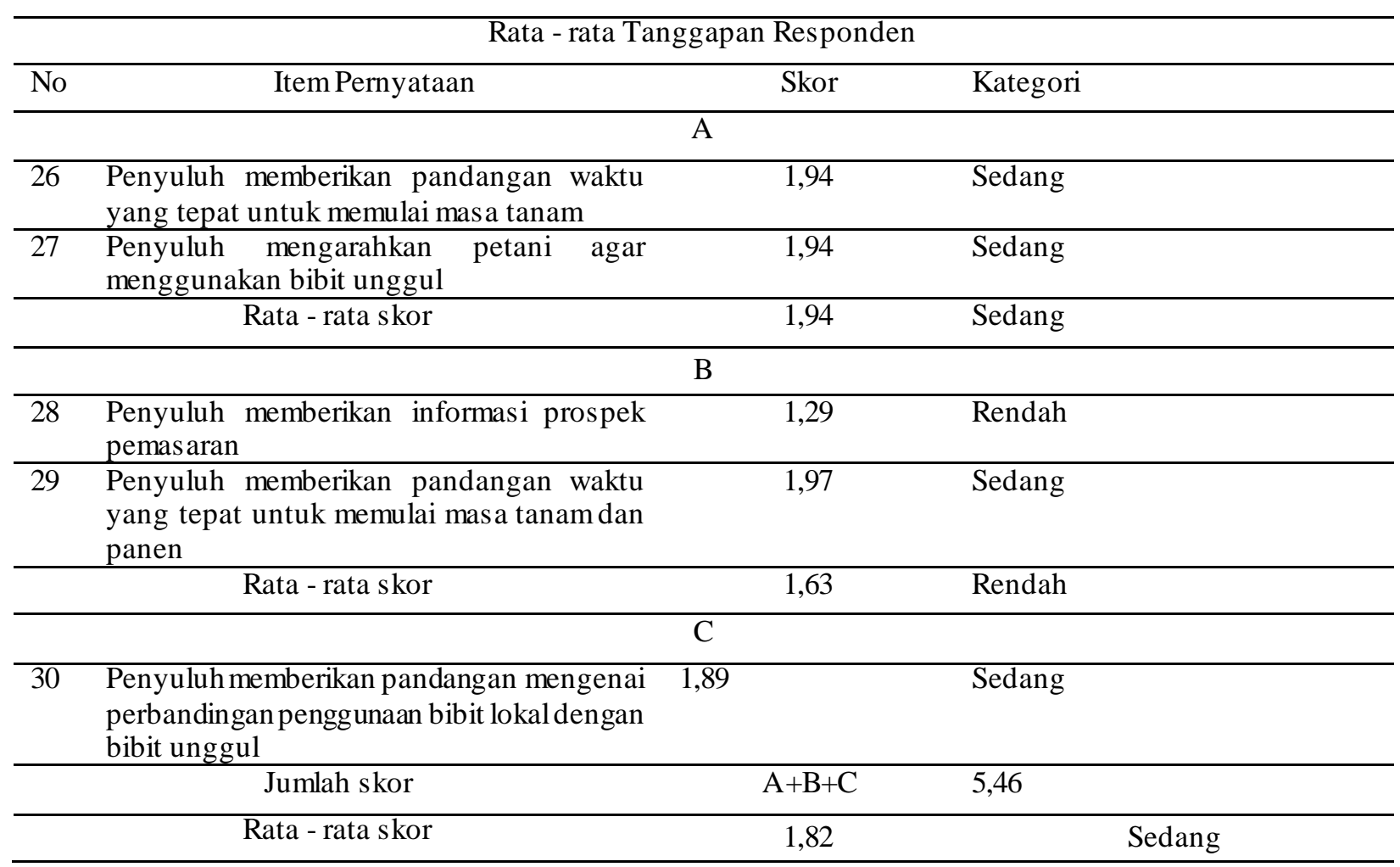

Sumber : Hasil Analisis Data, 2020

Berdasarkan Tabel 5 terlihat hasil ratarata nilai skor secara keseluruhan bahwa penyuluh sebagai agen pembahruan berada pada kategori sedang dimana rata-rata nilai skor sebesar 1,82. Hal ini menunjukkan penyuluh sudah melakukan tugasnya untuk memberikan informasi yang terbaru kepada petani. Menurut Mardikanto (1993) Peranan penyuluh sebagai agen perubahan adalah membantu petani membentuk pendapat yang 
sehat dan membuat keputusan yang baik dengan cara berkomunikasi dan memberikan informasi yang sesuai dengan kebutuhan petani. Peranan penyuluh lebih dipandang sebagai proses membantu petani untuk mengambil keputusan sendiri dengan cara menambah pilihan bagi mereka dan menolong petani mengembangkan wawasan mengenai konsekuensi dari masing masing pilihan tersebut. Berdasarkan uraian tersebut maka peranan penyuluh sebagai agen pembaharuan sangat penting serta perlu diperhatikan guna membentuk petani yang mandiri dan diharapkan dapat meningkatkan kesejahteraan petani. Sejalan dengan pendapat Winaryanto et al (2011) yang mengatakan salah satu komponen penting sehingga pengetahuan dan keterampilan (inovasi) sampai atau dapat diadopsi oleh petani adalah berfungsinya penyuluh sebagai agen pembaharu (change agent).

Untuk mengetahui seberapa besar peranan penyuluh pertanian terhadap petani padi di Desa Sambora Kecamatan Toho maka peneliti menjabarkan dalam bentuk tabel 6 berikut.

Tabel 6. Tingkat Peranan Penyuluh Lapangan Di Desa Sambora

\begin{tabular}{clcl}
\hline \multicolumn{4}{c}{ Rata - rata Tanggapan Responden } \\
\hline No & Peranan Penyuluh Sebagai & Skor & Kategori \\
\hline 1 & Penasehat & 1,62 & Rendah \\
\hline 2 & Organisatoris & 2,00 & Sedang \\
\hline 3 & Teknisi & 1,82 & Sedang \\
\hline 4 & Penghubung & 1,92 & Sedang \\
\hline 5 & Agen Pembaharuan & 1,82 & Sedang \\
\hline & Rata -rata skor & 1,84 & Sedang \\
\hline
\end{tabular}

Sumber : Hasil Analisis Data, 2020

Dari tabel di atas dapat diketahui bahwa peranan penyuluh pertanian terhadap petani padi di Desa Sambora Kecamatan Toho yakni sebesar 1,84 yang mana nilai tersebut termasuk kategori sedang. Artinya dari keseluruhan rata-rata nilai peranan penyuluh mulai dari penyuluh sebagai penasehat, penyuluh sebagai organisatoris, penyuluh sebagai teknisi, penyuluh sebagai penghubung dan penyuluh sebagai agen pembaharuan dinyatakan perannya sedang atau cukup bagi petani.

Peranan penyuluh yang berada pada nilai terendah berada pada peranan penyuluh sebagai penasehat yakni dengan rata-rata nilai skor sebesar 1,62 dimana termasuk dalam kategori rendah. Peran penyuluh sebagai penasehat rendah disebabkan penyuluh mengurangi kegiatan-kegiatan yang berhubungan dengan kontak fisik dan berkumpul dan mengganti metode komunikasi menjadi komunikasi bermedia, yaitu komunikasi melalui telpon, sms, dan what's up.

Nilai tertinggi berada pada peranan penyuluh sebagai organisatoris dengan ratarata nilai skor sebesar 2,00 dimana termasuk dalam kategori sedang. Skor yang diperoleh dapat menjadi tolak ukur bagi para penyuluh di Desa Sambora Kecamatan Toho agar bisa lebih meningkatkan peranannya.

Berdasarkan hasil wawancara terhadap petani responden diperoleh informasi bahwa dalam enam bulan terakhir hanya $8,57 \%$ petani responden membicarakan masalah yang dihadapi dalam usahatani mereka dengan penyuluh. Sebesar $77,4 \%$ responden mengatakan penyuluh tidak memberikan informasi berupa teknik budidaya, teknik pemupukan, teknik PHT, teknik pemanenan, informasi harga, informasi pemasaran, dan informasi pembentukan koperasi. Selain itu sebanyak 83,24\% mengatakan responden mengatakan penyuluh tidak memberikan 
informasi kepada petani secara kunjungan pribadi mengenai teknik budidaya, teknik pemupukan, teknik PHT, teknik pemanenan, informasi harga, informasi pemasaran, dan informasi pembentukan koperasi. Hal ini menunjukkan peran yang dilakukan oleh penyuluh dalam enam bulan terakhir menurun. Sejalan dengan hasil penelitian Wibowo dan Haryanto (2020), kinerja penyuluh pertanian dalam pembinaan kepada petani selama masa pandemi Covid19 ini mengalami perubahan jumlah kunjungan penyuluh pertanian ke sasaran, jumlah materi pembinaan yang diberikan, dan metode penyuluhan.

Peran-peran yang harus dilakukan sebagai penyuluh yaitu sebagai penasehat, organisastoris, teknisi, pendukung, dan agen pembaharu mengalami kendala untuk dilaksanakan karena adanya instruksi dari pemerintah pusat berupa Pembatasan Sosial Berskala Besar Dalam Rangka Percepatan Penanganan Corona Virus Disease (Peraturan Pemerintah nomor Nomor 21 Tahun 2020) dan daerah berupa pembatasan kegiatan sosial dan fisik serta adanya himbauan untuk menjaga jarak dan dilarang untuk berkumpul dalam kerumumunan menjadikan upaya untuk menyampaikan materi penyuluhan baik berupa anjangsana dan pertemuan kelompok tani menjadi terbatas. Selain itu kegiatan penyuluhan menjadi terhambat dikarenakan adanya penutupan akses hubungan antar kota bahkan dalam wilayah sendiri dalam hal ini Desa Tambora. Penutupan akses dan pengurangan kegiatan masyarakat dikenal dengan istilah Balala' ini digagas dan diputuskan oleh Dewan Adat Dayak desa bersama dengan perangkat desa. Dalam kurun Februari sampai Juni 2020, Pemerintah Desa Tambora melalui Dewan Adat Dayak beberapa kali melakukan penutupan akses keluar masuk desa dan melarang masyarakat desa untuk berkegiatan untuk waktu-waktu tertentu sesuai dengan situasi dan kondisi yang dipandang perlu untuk dilakukannya penutupan desa.
Pembatasan pergerakan masyarakat berdampak pula pada kegiatan yang harus dikerjakan penyuluh sehingga peran yang harus mereka laksanakan juga menurun.

Di masa pandemi peran penyuluh dalam usahatani padi di Desa Sambora masuk dalam kategori sedang. Hal ini menunjukkan disaat terjadi pandemi peran penyuluh masih berjalan karena walaupun sangat menurun. Semua peran terus dilakukan oleh penyuluh walaupun dengan adanya pembatasan fisik dan sosial demi mempertahankan keterlibatan petani dalam usahatani padi mereka. Peran penyuluh menjadi hal yang sangat krusial dalam rantai pasok pangan, ketersediaan pangan dan dalam rangka untuk mempertahankan ketahanan pangan di masa pandemic Covid 19 \{Sudarmansyah, et al (2021), Wibowo dan Haryanto (2020), Hirawan dan Verselita (2020)\}.

\section{KESIMPULAN DAN SARAN}

\section{Kesimpulan}

Peranan penyuluhan secara umum menunjukkan tingkatan sedang dalam upaya meningkatkan produktivitas padi di Desa Sambora dimasa pandemi. Pandemi Covid19 mengakibatkan perlambatan kegiatan penyuluhan, ditunjukkan dengan sebanyak $83,24 \%$ petani mengatakan penyuluh tidak memberikan informasi kepada petani secara kunjungan pribadi dan kelompok mengenai teknik budidaya, teknik pemupukan, teknik PHT, teknik pemanenan, informasi harga, informasi pemasaran, dan informasi pembentukan koperasi. Dampak pandemi juga mengubah metode komunikasi penyuluhan dari metode kunjungan secara langsung melalui pertemuan pribadi dan kelompok menjadi metode komunikasi bermedia.

\section{Saran}

\begin{tabular}{lcr}
\multicolumn{1}{c}{$\begin{array}{c}\text { Penyuluh } \\
\text { diharapkan }\end{array}$} & $\begin{array}{r}\text { lebih } \\
\text { peningkatkan }\end{array}$ \\
organisatoris, teknisi, & penghubung, \\
konsultan, dan agen & pembaruan. \\
Pendampingan, bimbingan, motivasi kepada
\end{tabular}


petani terutama pada pelaksanaan PHT, pembentukan koperasi unit desa lebih digalakkan lagi. Selain itu peran penyluh sebagai penghubung dengan peneliti, memberikan informasi pemasaran, memberikan pandangan waktu yang tepat untuk memulai masa tanam dan panen juga perlu ditingkatkan.

\section{DAFTAR PUSTAKA}

Antriyandarti, E. (2018, 3 November). Peran Koperasi dalam Pemasaran Produk Kelapa di Era Industi 4.0. Prosiding Seminar Nasional Program Studi Agribisnis Fakultas Pertanian Universitas Jember. 428432.

Faqih, A. (2014). Peranan Penyuluh Pertanian Lapangan Dalam Kegiatan Pemberdayaan Kelompok Terhadap Kinerja Kelompok Tani. Jurnal Agrijati, 26 (1), 41-60.

Hasan, I. (2014). Analisis Kinerja Koperasi Pertanian Dalam Tataniaga Komoditas Ekspor Di Kabupaten Aceh Tengah - Provinsi Aceh Dalam Menghadapi Persaingan Antar Negara Asean 2015. Jurnal Kebangsaan. 3 (6). 1-12.

Hirawan, B. F., Verselita, A. A. Kebijakan Pangan di Masa Pandemi COVID19. (2020). CSIS Commentaries DMRU-048-ID

Ilham. (2010). Ekonomi Pertanian dan Pembangunan. Bumi Aksara. Jakarta.

Inten, M. S, Elviana, CCW.D, Nover, R., B. (2017). Peranan Penyuluh Pertanian Dalam Peningkatan Pendapatan Petani Komoditas Padi di Kecamatan Tanjungselor Kabupaten Bulungan Kalimantan Utara. Agrifor: Jurnal Pertanian dan Kehutanan. 16 (1). 103-108.

Kurniawan, A. W, Puspitaningtyas, Z. (2016). Metode Penelitian Kuantitatif. Pandiva Buku. Yogyakarta.

Novianti, R. (2019). Pengaruh Media Pembelajaran Youtube Terhadap Hasil Belajar Siswa Pada Mata Pelajran Ekonomi Di Sma Pasundan 7 Bandung (Survey Pada Mata Pelajaran Ekonomi Dengan Materi Pendapatan Nasional Di Kelas Xi Ips 2 Tahun Ajaran 2018/2019). Skripsi. FKIP Universitas Pasundan.

Peraturan Pemerintah (PP) Nomor 21 Tahun 2020. Pembatasan Sosial Berskala Besar dalam Rangka Percepatan Penanganan Corona Virus Disease 2019.

Rahmawati, Mahludin, B., \& Bahua, M. I. (2019). Peran Kinerja Penyuluh dan Efektivitas Pelaksanaan Penyuluhan pada Program Intensifikasi Jagung. Jurnal Sosial Ekonomi Pertanian, 15(1), 56-70

Sudarmansyah, Ruswendi, Ishak, A., Fauzi, E., Yuliasari, S.,\& Firison, J. (2021). Peran Penyuluh Pertanian dalam Mendukung Ketahanan Pangan pada Saat Wabah Pandemi Covid-19. Jurnal Agribisnis, 14 (1), 1598-1612.

Sudjana. (2005). Metode Statistika. Tarsito. Bandung.

Sugiyono. (2016). Metode Penelitian Pendidikan Pendekatan Kuantitatif, Kualitatif, dan R\&D. Alfabeta. Bandung. 
Suhardiyono, L. (1992). Penyuluhan, Petunjuk bagi Penyuluh Pertanian. Erlangga. Jakarta.

Sukidin dan Mundir. (2005). Metode Penelitian: Membimbing dan Mengantar Kesuksesan Anda dalam Dunia Penelitian. Insan Cendikia. Surabaya.

Sundari, Abdul Hamid A.Yusra, A. H.A., Nurliza. (2015). Peran Penyuluh Pertanian Terhadap Peningkatan Produksi Usahatani Di Kabupaten Pontianak. Jurnal Social Economic Agriculture. 4 (1). 26-31.

Suparmoko. (2005). Metode Penelitian Praktis Untuk Ilmu-Ilmu Sosial Ekonomi. BPFE. Yogyakarta.

Syamsu, J. (2011). Reposisi Paradigma Pengembangan Pertanian : Pemikiran, Gagasan, dan Pencerahan Publik. Absolute Media. Yogyakarta.

Wardani, Anwarudin.O. (2018). Peran Penyuluh Terhadap Penguatan Kelompok Tani Dan Regenerasi Petani Di Kabupaten Bogor Jawa Barat. Journal TABARO 2 (1). 191-200.
Wibowo, T.H., Haryanto,Y. (2020). Kinerja Penyuluh Pertanian dalam Masa Pandemi Covid-19 di Kabupaten Magelang. Jurnal Penelitian Peternakan Terpadu. 2 (2). 79-92.

Wijaya A.S, Sarwoprasodjo S, Febrina D. (2019). Cyber Extension: Use Of Media And Information Search Strategy In The Agriculture of Agricultural Bogor District. Jurnal Komunikasi Pembangunan. 17 (2). 117-121

Winaryanto, S., Yunasaf, U., Rusmana, A., (2011). Profesionalisme Penyuluh dan Hubungan dengan Peran Penyuluh Sebagai Agen Pembaharu (Kasus pada Penyuluh Bidang Peternakan. Jurnal Ilmu Ternak. Universitas Padjajaran. 11 (1). 24-35

WKPP Kecamatan Toho. (2020). Programa Penyuluhan Pertanian WKPP Kecamatan Toho.

Zulfikar, Amanah, S., Asngari, S, P. (2018). Persepsi Petani terhadap Kompetensi Penyuluh Pertanian Tanaman Pangan di Kabupaten Aceh Utara. Jurnal Penyuluhan. 14 (1). 159-174. 